\section{CONCEPTION OF THE WORLD CREATION MYTHS CONTAINED IN ISAN FOLK LITERATURES ${ }^{1}$}

\section{Thanya Sungkhapantanont ${ }^{2}$ Surathdchanukoon Nunphooban ${ }^{3}$}

\section{บทคัดย่อ}

บทความนี้ มุ่งศึกษาแนวคิดการกำเนิดมนุษย์ของชาว อีสาน ผ่านงานวรรณกรรมพื้นบ้าน จำนวน 3 เรื่อง คือ ตำนานปู่สังกะสา-ย่าสังกะสี ปฐมปันนา และตำนาน น้ำเต้าปุ้ง โดยใช้แนวคิดองค์ความรู้เชิงนิเวศแบบ ดั้งเดิม มาเป็นกรอบแนวคิดในการศึกษาแล้วนำข้อมูล ที่ได้มานำเสนอเชิงพรรณนาวิเคราะห์

ผลการศึกษา พบว่า ตำนานเรื่องปู่สังกะสา-ย่าสังกะสี และปฐมปันนา สะท้อนแนวคิดองค์ความรู้เชิงนิเวศ แบบดั้งเดิม คือการคิดแบบองค์รวม เนื้อหากล่าวถึง การกำเนิดโลกจากอากาศธาตุ(ลม) พัดจนเกิดเป็นน้ำ

\footnotetext{
1 (แนวคิดการกำเนิดมนุษย์ในวรรณกรรมพื้นบ้านอีสาน) This article is adapted from the doctoral dissertation "The traditional ecological knowledge of Isan traditional literature" Doctor of Philosophy Program in the Thai Mahasarakham University. 2 (ธัญญา สังขพันธานนท์) Associate Professor at Faculty of Humanities and Social Sciences, Mahasarakham University.

3 (สุรธัชนุกูล นุ่นภูบาล) Ph.D.candidate, Doctor of Philosophy (Thai), Faculty of Humanities and Social Science, Mahasarakham University.
}

ลมพัดน้ำกลายเป็นดิน ลมพัดดินกลายเป็นหิน จากนั้น เกิดมีต้นไม้ และเกิดเป็นสัตว์และมนุษย์ตามมา ทั้งนี้ “องค์ธรรมมา" ได้ถูกนำมาอธิบายความหมาย เชิงสัญญะ (Sign) ของลม องค์ธรรมมาได้สร้างปู่สัง กะสา-ย่าสังกะสี ตัวปู่สังกะสา-ย่าสัง กะสี ได้สร้างสรรพสิ่งขึ้นบนโลก ตัวปู่สังกะสา-ย่าสังกะสี จึงเป็นภาพแทน (Representation) ของธรรมชาติ แสดงให้เห็นว่าแนวคิดองค์ความรู้เชิงนิเวศแบบ ดั้งเดิมของคนอีสาน มนุษย์ถือกำเนิดจากธรรมชาติ นั่นเอง

ตำนานน้ำเต้าปุ้ง พบว่ามีแนวคิดเรื่องของการใช้ สัญลักษณ์น้ำเต้าแทนครรภ์ ของสตรี การให้ วรรณกรรมแสดงการ ไหลออกมาจากน้ำเต้า แสดงให้ เห็นว่าคนอีสานให้ความสำคัญกับน้ำเต้าปุ้งในฐานะ เป็นพืชชาติเป็นจุดกำเนิดของมนุษย์ การตายของควาย ก่อให้เกิดน้ำเต้าแสดงให้เห็นว่า คนอีสานมองเรื่อง ของการตาย มิใช่เรื่องการฆ่า แต่เป็นการมองว่าการ ตายนำมาซึ่งการก่อกำเนิดชีวิตใหม่ สะท้อนการมอง ถึงความสัมพันธ์ระหว่างมนุษย์และธรรมชาติ

กล่าวโดยสรุปวรรณกรรมพื้นบ้านเรื่องปู่สังกะส่า ย่า สังกะสีเป็นตำนานที่แสดงถึงแนวคิดเชิงนิเวศแบบ ดั้งเดิมเรื่องของจักรวาลทัศน์ ตำนานน้ำเต้าปุ้งเป็น วรรณกรรมที่อธิบายการตายของควายเป็นการ ก่อกำเนิดชีวิตใหม่ อธิบายน้ำเต้าเป็นสัญญะของ ธรรมชาติ แสดงถึงความเป็นพืชชาติในฐานะต้น 


\section{กำเนิดของมนุษย์ น้ำเต้าปุ้งจึงเป็นภาพแทนของ ธรรมชาติ เป็นเทพมารดรของคนอีสานนั่นเอง}

\begin{abstract}
This paper focuses on pieces of Folk Literature investigating Isan people's conception of the myths of World Creation contained in two Folk Literatures; the Legend of 'Pu Sangasa-Ya Sangasi' and 'the Legend of Nam Tao Pung'. Traditional Ecological Knowledge is used as a conceptual framework for this study. The data gained from the study was then descriptively reported via the process of analysis.
\end{abstract}

The results found that 'the Legend of Pu Sangasa-Ya Sangasi' reflects traditional ecological knowledge as a holistic thinking concept. The contents of the work explain that the world was created by the wind blowing until there was water. Water was blown until it became soil and then from soil to rocks and rocks to plants. After that, human beings and animals were created. In addition, there was 'Lord Dharma' described in the content as a sign of wind. 'Lord Dharma' created Pu Sanga Sa-Ya Sangasi as well as all the creatures of this world. Consequently, Pus Sangasa- Ya Sangasi was a representation of Nature. Isan people's traditional Ecological knowledge therefore inferred that human beings were created by Nature.

Meanwhile, 'The Legend of Nam Tao Pung' is a story presenting the concept of using 'Nam Tao' as a sign which refers to female pregnancy. In the work, everything is of born and got out from Nam Tao onto the land. It means that Isan people recognize the importance in Nam Tao as the birthplace of human beings. The death of Buffaloes and cows caused Nam Tao to be born. This story tells us that Isan people believe that someone dying was not about murder but it was the beginning of a new life to be born. It also reflects the relationship between human beings and nature.

In conclusion, 'the Legend of Pu Sangasa-Ya Sangasi' is a work explaining the traditional ecological knowledge of the Cosmology. On the other hand, 'Nam Tao Pung' describes the death of buffaloes as the origin of new life. 'Nam Tao' is presented in the literature work as a sign of nature where human beings were born. Therefore, 'Nam Tao Pung' becomes the sign of the 'Mother God' of Isan people.

\section{Introduction}

Originally, Isan Folk literature was communicated orally. Later, these stories were recorded more in written format. Some Isan Folk works were written on leaves such as Bai Larn and Koi which were used as paper in former times. The Dharma and Thai Noi alphabets were used for recording these works before the new technology of printing was developed. Also, the trend of using Dharma and Thai Noi alphabets faded in the Isan region. Since then, Isan folk literature has been translated into Thai using the modern Thai alphabet. A study of literature and the meaning of literature can also introduce us to people's ways of life, values, ideas and cultures; including, for instance, how to describe natural phenomena such as the creation of the world and the creation of human beings which are conceptual ideas of cosmology. 
The conception of the creation of human beings is found in the Isan folk tales. The first one is Pu Sangasa-Ya Sangasi. This is the story of the male and female creator types saying that, firstly, there was only an empty world and empty universe but later the Lord Dharma appeared on earth and the wind blew to create the land and the Lord Dharma created the first couple of human beings who were male and female, namely, $\mathrm{Pu}$ Sangasa and Ya Sangasi. Then, the couple moulded creatures from clay to make human beings and animals. They taught the human beings and animals how to live their lives and have their own families. After that, $\mathrm{Pu}$ Sangasa-Ya Sangasi created the lands and divided them into continents; they also created water lands, mountains, heavens, hell, world and universe which are believed to have existed until now. The second story is 'Nam Tao Pung'. This narrates the belief in Phraya Taen as the creator of the world and human beings. It is said that human beings were born and poured out of the sacred gourd or gourd type. Phraya Taen was the one who ordered his soldiers, namely Khun Kek and Khun Kan, to build the land called $\mathrm{Na}$ Noi Aoi No. He also sent buffaloes down to the land to help human beings work on their farms. When the buffaloes died, they became plants and these plants produced fruit called Nam Tao or gourds. This sacred gourd sprang out of the buffaloes' noses. Inside the sacred gourd was a place where human beings had originated and were living. Then, the two soldiers drilled the sacred gourd with a chisel made of heated steel to make a hole and allowed the human beings to be poured out.

This article highlights the study of the myths of the creation of the world creation and human beings as well as the description of the importance of nature found in Isan Folk Literature by implementing Traditional Ecological Knowledge as a framework for describing information. Based on the conception proposed by Pierotti and Wildcat, Traditional Ecological Knowledge consists of 1) an acceptance of nonhuman as individual and 2) a recognition of bonding or the relationship between human and nonhuman, and the combination of the nonhuman and the ethical code of human behavior, 3) the advantages and importance of landscape and 4) an acceptance that humans are part of the ecosystem. Whereas, Berkers (2010) suggests the following about the conceptual frame of traditional ecological knowledge; 1) Traditional Ecological Knowledge is quality; it is opposite to quantity, 2) Traditional ecological knowledge always includes instinct; it is not only the causes and reasons for something, 3) Traditional ecological knowledge is holistic thinking, 4) Traditional ecological knowledge is a combination of object and mind together, not the separation of object from the mind, 5) Traditional ecological knowledge is morality, 6) Traditional ecological knowledge is about the spiritual. 7) Traditional ecological knowledge is based on experience accumulated and gained from observation and a long-term trial \& error process, 8) Traditional ecological knowledge is based on the information obtained by the use of local resources, not by the process of knowledge searching from those who are experts or the research process and 9) Traditional ecological knowledge is based on historical data; it takes a long time to organize the data into a sequence and it does 
not aim to control nature (cited in Thanya Sungkhapantanont, 1990: 57).

To sum up, Traditional Ecological Knowledge means "a conception referring to the relationship that binds human, nature and the environment together. It is the way to respect nature, to learn how to live with nature and to hold nature as the center of the universe". This is a collection of the local wisdom of Isan people which has been accumulated from generation to generation over a long period of time.

\section{Research Methodology}

In order to highlight the importance of nature, nature-center is an important conceptual idea of traditional ecological knowledge. The research methodology is mixture of criticism on Eco criticism and Folklore Theory.

The myths of world creation and human creation (cosmology) of people in the Isan region are found in many folk works; including, Nam Tao Pung or Khun Borom, $\mathrm{Pu}$ Sangasa-Ya Sangasi, Patommamoonpanna, Patommabot and Patommakappa.

According to the study, although the titles "Patommamoonpanna, Patommabot and Patommakappa" are different; the plots and content of the three legends are similar. When compared with Tibhava or the three planes of existance which is influenced by Buddhism, it is found that all the stories have similar content.

On the other hand, in the first chapters of both stories, "Nam Tao Pung" and "Pu Sangasa-Ya Sangasi", it is claimed that they are taken from the Lord Buddha's teachings delivered for the 500 Arahants; the contents are different from the three stories mentioned earlier. These two legends are inserted with local beliefs together with the Lord Buddha's teachings. Therefore, these two works are a kind of "Buddhism of Local people". Consequently, the author selected these two pieces in order to study the world creation conception from the Isan people's traditional ecological knowledge perspective.

\section{Literature Review}

The review of literature found that Siraporn $\mathrm{Na}$ Talarng (1996) studied the myths of world creation; the data collection was conducted through field study, documentary study and verbal folklore. The data gained from the study was analyzed by classifying the sequences of the stories into traits and motifs and tale types. The legends were classified into groups regarding the relationships in cultures between different groups of Tai people contained in the myths of world creation in a process known as 'the theory of tale transmission'.

According to the result of the study, Siraporn Na Talarng suggested that most myths of world creations of Tai people share the same culture which is a rice culture. For the Tai people's belief of world creation, formerly, there are two traits; the belief in $\mathrm{Pu}$ Sangasa-Ya Sangasi and the belief in Nam Tao Pung as the creator of humans. These are the traditional beliefs held by Tai people before the propagation of Buddhism. Later on, they adopted the principles of Buddhist and combined the Buddhism conception and spiritual belief together. 
The author brought the conceptions contained in $\mathrm{Pu}$ Sangasa-Ya Sangasi which is believed to be the creator of humans to be decoded for its natural signs in order to synthesize and find out that how Isan people emphasize the importance of ancestor worship; as well as, Nam Tao Pung as the sign that reflects the conception of an emphasis on the importance of nature and living with the nature respectfully as well as holding nature as the center of cosmology.

\section{Results of the Study}

Isan people's Conceptions of Traditional Ecological Knowledge toward Cosmology are found in which Isan Folk Literatures, such as, $\mathrm{Pu}$ Sangasa-Ya Sangasi (Grandfather Sangasa-Grandmother Sangasi), the Legend of Nam Tao Pung or the Myth of the Sacred Gourd as well as Khun Borom and Kao Kruae Gard. Each of these folklores is told in different styles of language but the former plots are not much different. This is to examine the imprints of Tradition Ecological Knowledge in Isan people's opinions. According to the study, it was found that the contents in these pieces of folklore concern the myths of the creation of human beings in following two conceptions.

1. Human beings were born from Nature (wind)

To investigate Traditional Ecological Knowledge, the researcher used the story of "Pu Sangasa and Yah Sangasi" whose original format is written with Dharma alphabets as a tool for studying. This original edition was translated into Thai Noi by Dhanupol Chaiyasit and published in
1994. In addition, the second work used for this study is Patommabhumi Panna (the primary information of the world creation) which was formerly written on Bai-Larn or palm leaves, in short folk tales using the Tai Noi alphabet by Suphon Somjitsripunya, found at Wat Bannhonglom, Donwaan Subdistrict, Maung District, Mahasarakham Province. The Thai-translated edition was published in 1992. Both versions are written in poem form.

In the first part, the work "Pu Sangasa and Yah Sangasi" is the explanation of the myths of world creation, telling that the world was formerly lonely and empty. There was no sun, moon, humans, animals, hell or heaven, etc. Later, there was wind blowing and there appeared the Dharma. When the wind blew, it created fish and the earth respectively. The explanation of these sequences represents the evolution of the Isan people's conception of the origins of the world; it explains what comes first and what comes after as follows:

\author{
"There was an empty space \\ where nothing can be found \\ at here \\ Not to be seen everything to be \\ such an emptiness \\ One day, at first the God wind, \\ Wayo, \\ the Lord Dharma did appear \\ Here came he blew in the air" \\ (Dhanupol Chaiyasin, the Legend of $\mathrm{Pu}$ \\ Sangasa-Ya Sangasi. 1994: 2)
}

According to the poem, the content explains the creation of the world that the world was formerly a place of loneliness and emptiness. Then, the wind was created as the Lord 
Dharma who appeared to create everything on earth. Suphon Somjitsripunya (1992) also stated that "the Dharma" appeared on earth before other things in an analytical article, 'Moon Patommapanna' as follows:

"Primarily, there was no angel, no Lord Buddha, no humans, no animals, no hell, no heaven, no soil, no water, no sun and no Moon. There was only empty air. Then, at first the Dharma appeared. Later on, there was a wind blowing water to create a fish called Ananta"

\section{(Suphon Somjitsripunya, Moon Patom}

Panna. 1992: 3)

It can be seen that the meaning found in the content of Pu Sangasa and Yah Sangasi is about the importance of nature and to explain the causes and effects of what happened at the time. According to the statement, "at first the God wind, Wayo, the Lord Dharma appeared", the word 'Wayo' in Pali means "wind" which naturally existed. Wind is then the representation of the nature. However, to make it more concrete, the content is described in form of the Lord Dharma which refers to Nature. This content is related to the "primary data, the National Library edition", in the study of Thanya Sungkhapantanont (2013) that the world was formerly empty; there was nothing, only summer and winter. After the two elements were merged together; they were formed into the wind, followed by water and minerals. That was believed as the origin of life on the earth later on. In addition, Thanya Sungkhapantanont also pointed out that this conception correspondingly agrees with the scientific theory that the evolution of organisms began from tiny organisms which had been adapted over a long period of time until becoming a perfect life form (Thanya Sungkhapantanont, 2013: 93-94).

The meaning of Tradition Ecological Knowledge in the concept of the Isan people, described through the creation myth of the world, can be briefly summarized that the world originated from emptiness. Literally in the conception of Traditional Ecological Knowledge, it can be claimed that this conception is based on historical information because it took such a long time in organizing the data without any attempt to control the nature. The first and most important thing as the origin of all creatures stated in the literature an energy. This kind of energy is 'wind'. When the wind blew, it created air (oxygen). When the air reached the proper temperature; later, other living creatures existed. Scientifically, this phenomenon is described as the status when there is something different occurring in the air. Exchanges between hot and cool air caused the wind. This explanation corresponds to Berkes (2010) that the background set of Isan people's Tradition Ecological Knowledge is based on historical Information. Previously, in the ancient time of our ancestors, the creation myth of the world was told with a belief in Nature; and certainly, when talking about belief, there is something super spiritual hidden within. "When the atmosphere changes, other parts of the world transfer heat energy from one to another where wind and water are their center. This phenomenon caused other things in this world to happen. There are seasons turning by changes in times." This conception is brought into a set of ideas globally. The wind or air is like the origin of 
everything on earth and described in the creation myth of Isan people. After the world was created, "wind or the Lord Dharma" built the first couple of male and female on earth, namely, $\mathrm{Pu}$ Sangasa-Ya Sangasi. Later, both of them lived on land covered with soil and trees in the forest which is explained in the content that:

"(Wind) blew to create male and female to live on earth with trees"

\section{(Suphon Somjitsripunya, the Legend of Pu} Sangasa-Ya Sangasi. 1992: 20)

According to the content of the work, 'Pu Sangasa-Ya Sangasi', there is the explanation of the first male and first female couple that they were created by the wind. It describes the way human beings lived with the nature, soil and trees; and then the first human couple had to adapt themselves to perfectly live within the nature and environment. Recognizing nature as God (the Lord Dharma) and the creation myth of the world in Isan people' view corresponds with the conception described in scientific principles that changes of climates cause living creatures which are Prokaryotic cell types existed as the first types of all creatures on earth (Mattanee Yomjinda, 1998).

The legend of "Pu Sangasa and Ya Sangasi" is a story describing the creation of the first male and female couple (Male and female creator type) on earth. It highlights the explanting how the creation of the world, human beings, plants, animals and continents; including, hell and heaven. $\mathrm{Pu}$ Sangasa and Ya Sangasi were the creators of everything. After being born, Pu Sangasa and Ya Sangasi made animals by molding clays and made them alive. After that, they made human beings both males and females. This is like the primary stage of the human creation in this world as found in the content of the literature as follows:

"Then, the Lord put his on his hands and feet, rubbed his eyes and necks grabbed some soil and water and mixed together with proper weight and 5-6 feet height He moulded it made a shape as a male

This one looked strong had beard since he turned its face down on the ground"

(Suphon Somjitsripunya, the Legend of Pu Sangasa-Ya Sangasi, Palm-leaf inscription no.16. 1992:10)

According to the work 'Pu Sangasa-Ya Sangasi', Pu Sangasa and Ya Sangasi were the first human couple of the world. It says that the female has a slender body, big breasts and nipples for breastfeeding. On the other hand, the male has a big and strong body, moustache and beard because the Lord Dharma laid his face down onto the ground where grass and soil attached to his face looking messy. The work narrates how $\mathrm{Pu}$ Sangasa and Ya Sangasi were created with their specific characteristics to indicate duties according appropriate to their genders which were then followed by their cultures. According to the evidence found in the literature in the Isan people' tradition ecological knowledge conception, was the Belief that Pu Sangasa and Ya Sangasi were the God father and God mother of human beings. They were relative spirit who created 
the world and all human beings. It is also an evident found in ancient Isan language that Isan people usually put the word "Sang" before the names of deceased people. The word 'Sang' may be the same as 'Sang' in the dictionary of the 'Isan-Central Thai Language', the edition of Somdet Weerawong (Tissamahathera) published in 1972 (1972:401) in which it verifies that 'Sang' is a noun used for calling the deceased persons such as, $\mathrm{Pu}$ Sang (deceased grandfather) and Ya Sang (deceased grandmother). However, the word 'Sang' is used for only respected persons of us. Sang is from "Sarng or Phi Sarng" (Phi means ghost); calling $\mathrm{Pu}$ Sangasa-Ya Sangasi is then the way of the deceased relatives or relative spirits.

The story of "Pu Sangasa and Ya Sangasi" explains us that $\mathrm{Pu}$ Sangasa and Yah Sangasi were created by the Lord Dharma or the wind. It also describes the first human couple's way of life where both of them "lived with soil and trees". This statement ecologically implies that human beings have been living close to the nature with deep relationship since the primary period. It is an acceptance of that human is a part of the ecology, which is nature center conception which is categorized as holistic thinking. It is an acceptance that humans are a part of the ecology, which is a nature centered conception which is categorized as holistic thinking. This means to say, human beings had to adjust and adapt their ways of life to fit into the nature; relying on earth as the place for living and tree as home. The content also describes that when plants grew, $\mathrm{Pu}$ Sangasa and Ya Sangasi moulded planteating animals and animal-eating animals to balance the number of plants and animals at the same time.

Consequently, human beings are part of an ecosystem. During the creation of the world, humans were part of the ecosystem; and everything was organized into a food chain system where all were reliant on each other. The literature reflects that all creatures and things existing after $\mathrm{Pu}$ Sangasa and Yah Sangasi had lived together. "They both created a tree climber namely Mai Duae and created animals from clay and fed them with grass. When the number of animals came together; the opposite types of animals were created to get rid of the other." That was the introduction of the first hunting. The literature also explains the concept of ecological management as follows.

"As being intelligent and smart, they grew a climbing tree, namely, Mai Duae Krue Kao There was everything they wanted Even grass has remained until now Whatever they wanted was once created They made donkeys, along with lions to hunt These animals were enemies that fight to keep the balance of the nature

Since too large a number of animals may be too crowded on earth in nowadays"

(Suphon Somjittasripanya, 1992: 20)

As mentioned above, there is a clue giving us some information about Traditional Ecological management found in the 
literature. It also illustrates how the management correlates with space allocation meaning something increase until they become too many; other things in the same environment will be affected. Therefore, the management to make a balance in an ecological system inferred from the literature is creating enemies or the opposite side to reduce the large number of those animals. The content of the literature explains, "when the created forest was completely filled with grass, plant-eating animals were also created to eat the plants; and when there were too many plant-eating animals, Pu Sangasa-Ya Sangasi created meat-eating animals to be animal eaters." The most interesting point is about creating human beings which can be both plant eaters and animal eaters". This concept agrees with Thanya Sungkhapantanont (2013) that this is a concept of traditional ecological knowledge regarding how to keep balance of space for living. It is about the relationship between one living thing and other living things on earth (Thanya Sungkhapantanont, $2013: 102)$

Apart from how to control the balance in the ecosystem, the literature also tells us how to reproduce their next generations by having sex. Both of them created a couple of male and female and taught them how to live their lives as well as how to eat rice and fish. The following poem is to give an example of the content that illustrates the ecological system.

"Thinking of living things on earth, They put them into couples

Not yet being taught the way of reproduction

Most animals with sexual desires could practice on their own
$\mathrm{Pu}$ Sangasa and Yah Sangasi had created hundreds of people One group out of them were men And another group were women What to do to make them eat to grow up

Then, having them eat some rice was great to make them strong Later, such eating of rice was told via word of mouth, People have rice and fish as food And have been living with rice and water until nowadays."

(Dhanupol Chaiyasin, 1994: 4)

It can be seen that the literature can reflect the meaning, linkage and relationship between plants, animals and human beings and implies that they were in the same food chain. It is an ecological management in a natural environment with reasonable causes and effects. This is not only one-way of thinking but it includes the whole concept of the management system to make balance. Especially, the literature also concerns human beings as the creatures living their lives by "eating both plants and animals". This conception states that human beings are the topmost in the food chain as predators. With the status of predator, human beings have more physical development than other kinds of animals since the ancient times.

The literatures describing the creation of human beings, including the evolution of creatures living on earth through the Isan creation myth can be put together into a thinking system to reflect a traditional ecological system based on the holistic way of thinking. It is obvious that the literature suggests that the world was created from air 
(wind). When the wind blew, it became water, from water to soil, soil to rock, and rock finally became a tree. When there were trees, there were animals and human beings. Therefore, the idea of creating predators to control the number of natural resources was born. This is a highlight and great evolution for human beings to adapt their lives to be able to live with the nature among tress and on the land which are the symbols of nature. Since then, human beings have been trying to control nature by preying on animals for food and living.

\section{Humans are a part of Nature}

The conception of traditional ecological knowledge in Isan folk literature regarding the myths of world creation and human beings is another conception that the researcher has found being recognized and represented in term of importance to the nature. Nam Tao or a sacred gourd was used as a symbol of nature. Moreover, it was a sign representing a plant type within the traditional knowledge of Isan people.

The legend, 'Nam Tao Pung' explains that Nam Tao was born in a buffalo's nose after the buffalo died. The buffalo is represented as the sign of plenty. It saves human beings' lives and helps them cultivate rice. Consequently, Isan people recognize that buffaloes are important animals as their ancestors. In the work, 'Nam Tao Pung', the content narrates that after the buffalo died, there was a sacred gourd born inside its nose. Later, when Nam Tao Pung died, people poured out of it. This conception implies that to die is to begin a new life. The death of the buffalo in the work, 'Nam Tao Pung' is found inherited in form of sacred ceremonies. Many local communities bring buffalo for worshipping although killing buffaloes may look cruel. In conception of tradition ecological knowledge the death of buffaloes in Isan folk literature, Nam Tao Pung, caused Nam Tao to be born. Nam Tao later became a human being. This is simplified to the death of buffaloes being the origin of human creation. There is another belief that the death of buffaloes is a symbol of blood. The red colour of the blood can be described in traditional ecological knowledge that blood is an energy that causes new life to be born. It is similar to the blood of the female period which implies the readiness to be pregnant and to give birth to the newborn. To take blood for worshiping indicates the process of creating new lives of human beings.

Nam Tao or a sacred gourd is a symbol representing the female uterus or pregnancy or the mother who gives birth to the newborn. Nam Tao contains a lot of seeds and reproduces by seeding onto the ground. Its special characteristics are ease of growth and quick reproducing; thus it is able to illustrate the way that people poured out of this sacred gourd when Phraya Taen drilled a hole in it. Drilling a hole on the gourd can be seen as the symbol of human's sexual practice. The gourd is like a big female uterus of the God mother for giving birth to animals, plants and human beings. In comparison, the way that human beings poured out from the gourd is similar to the seeds of the gourd that are easy to plant and quickly reproduced. This is born from the concept of killing for worshiping. The death of plants indicates the way of thinking in the traditional ecological conception of Isan people which is related to the meaning 
concerning the growing process of plants because most plants must die before they can reborn once again, for instance.

According to the literature, it can be seen that the conception of humans created from Nam Tao may be drawn from the shape of Nam Tao which looks like the female uterus. Nam Tao indicates the natural symbol describing that people poured out from the gourd when the two soldiers drilled a hole in it is in the way that human beings having sexual practices. Nam Tao is like a big female uterus of the Mother Goddess who created animals, plants and human beings. The way they poured out from the gourd also means that they were born from the same Nam Tao or the same mother; then, all ethnic groups of human beings pouring out from the same gourd are all brothers and sisters or the same types. They had the same mother or same origin which is a gourd.

This conception agrees with Siraporn $\mathrm{Na}$ Talarng that the legend of 'Tai Ethnic Group' in the analytical book of the Tai creation myth describes the ethnic groups of people in the North of Usakaney (Southeast Asia). The legend describes how different ethnic groups are created from generation to generation. It is popularly told by the people in this area. Consequently, the hierarchy of ethnics is arranged differently. For example, some legends arrange the ethnic form Viet, Lao, Jam and Mon; in Lo Lo legend, there are Yao and Lao and in Yao legend the people who poured out from the gourd are divided into different categories. As a result, traditional ecological knowledge is not only widely expanded among the group of Isan people and the group of people speaking Tai-Lao; it includes groups of people speaking Austro-Asiatic or Mon-Khmer, such as Lua, Lawa and Kha. This is different and dependent on the different legends of different groups of people (Siraporn $\mathrm{Na}$ Talarng, 2002:84)

The legend of Nam Tao Pung indicates that human beings are originally from the hole in the Nam Tao which was drilled by the two soldiers. Nam Tao is a type of natural plant. After the hard rain; and the world being flooded, Phraya Taen sent buffaloes to help people work on their farms. When the buffalos died, the gourds were born in the buffaloes' noses and when the gourds died the soldiers of Phraya Taen drilled holes in the gourds to make human beings pour out. In terms of traditional ecological knowledge in sociological characteristics, this is the way to take advantage of nature. When people in societies knew how to cultivate plants, they noticed that plenty of the land and crops were created by soil and sky (rain). These are related to each other in terms of agricultural society. Then, people changed from worshiping the images of the animals they killed to worshiping the god of land and sky instead. The land is like a female uterus or the tunnel of life; it is a symbol of being father and mother, soil, Phaya Taen, Naga, Frog and the Goddess of land. All of these are composed to represent the sign of plenty with rain. Creation and growth of plants is like the birth and growth of human beings. The Sky or the god of lights, the sun and the sky represent male that provides plenty and nutrition for crop seeds. Soil reserves the rains; then, the land is like the female uterus that depends on the rain or water from the sky as sperms pouring down and into the uterus, representing human sexual practices. Consequently, rain is like the sperm that originates reproduction process and 
stimulate plants to grow. When the rain fell on the ground, it is like the god of the sky made the god of the ground become pregnant. (the land = female). The god of the ground or the land is like a mother who gave birth to crops. Consequently, this conception was originally born from the society of agriculture that worships the god of the land. Similarly, Berkes (2010) defined that traditional ecological knowledge also includes 'instinct' which is contrast to 'Same cause of Action'. In addition, traditional ecological knowledge is a combination of materials - agricultural products- which are sentimentally valuable together. It combines beliefs in deities of the sky and deities of the land into the way of agricultural society in Isan region.

To sum up, the legend of 'Nam Tao Pung' is the work describing the conception of traditional ecological knowledge. It presents the characteristics of male and female in the natural way through Isan Folk literature. In the traditional agricultural society, people pay attention to the importance of the women as effective factors in cultivation and production. Women played roles in storing crops and the secrets of cultivation. They were like the goddess who can grow their crop with fruitful products. In the work, Nam Tao Pung, Nam Tao is compared with a uterus of plant type. When human society was developed and people gathered in groups, became the age of the predator. At this time, men were seen to be more important than women as they acted as the predator. Predatory activities brought about death; however, death caused rebirth in terms of traditional ecological concept. The legend of Nam Tao Pung regards that after buffalos died, the gourd were born and when the gourd died people poured out from the dead gourd. This legend reflects the concept that death is like the symbol of rebirth, for instance.

\section{Results of the Study}

According to the study of 'the Legend of $\mathrm{Pu}$ Sangasa-Yah Sangasi' and 'the legend of Nam Tao Pung' or 'Khun Borom', regarding the creation of humans, it is found that the both legends suggest that Isan people and those who live in the communities along Mekhon River have a conceptual idea that recognizes the importance of nature as the center of cosmology.

1. The legend of $\mathrm{Pu}$ Sangasa-Yah Sangasi is the work describing earth being created from the wind. It is said that blowing winds changes rocks into soil. $\mathrm{Pu}$ Sangasa and $\mathrm{Ya}$ Sangasi were then born. After that, they created humans, stars, the moon and the sun from clay. They respected nature as it is the beginning of everything in this world. It could be said that this is kind of naturalism or spiritualism or a belief in paying respect to the nature or the relative spirituals. This is possibly the traditional concept of the people living in this area in the ancient period.

2. The legend of Khun Borom or Nam Tao Pung is a work narrating the people in different tribes that were all born in Nam Tao Pung or the sacred gourd. The different condition of birth made them become different in status. The first 
group of people was born when Nam Tao was drilled with hot steel; smoke from burning made their complexions dark. The other group of people was poured out from the sacred gourd through the hole drilled by a chisel and they were not burned. They had white complexion. When considering the story of Khun Borom, it can be seen that the literature describes the historical background of Lan Chang Empire inserted with contexts giving meaning and rights to the rulers of Lan Chang Empire. These people were all white people; their white complexion indicates the dominant class.

$\mathrm{Pu}$ Sangasa-Yah Sangasi narrates the creation of the first couple of male and female (Male and female creator type) which is about Ancestor Worship. The content shows that everything was created from the wind blowing (nature). It is a relationship to nature revealing the cultural belief of naturalism or nature worship hidden behind.

At the same time, the legend of Khun Borom or Nam Tao Pung describes the creation of humans which were born with different complexions, different ways of life and different identities. The literature describes each group of people being born in Nam Tao or the sacred gourd. They were delivered from the sacred gourd in different ways and this condition made them born with different social roles and statuses. The literature indicates something about the power and status of people in different social classes. Moreover, the people in the upper class were considered as group of rulers and higher than the others. This is called "Phra Ya Taen's Commands".

\section{Discussion}

The literature "Pu Sangasa-Ya Sangasi" reveals the culture shared among the people living along Mekhong River that everything was created by the "Lord Dharma or God". The beginning of humans is from the wind (nature). It is believed that the Lord Dharma is the creator of the world. This belief may be influenced by Hinduism. Since before Buddhism spread through the countries in southeastern Asia: Cambodia, Chawa or Indonesia, Bali, Sumatra, Malayu, Funan and Thailand; this region was influenced by Soivism. The Sovism priests, Brahmins, merchants and royal families had brought Indian culture to be propagated in this region; the conceptual idea regarding the world creation of Brahmins made the local people believe and hold together with their former belief which was Animism.

Describing the creation of human beings as well as the revolution of living creatures on earth through the world creation myth of Isan people can be respectively seen as hierarchical thinking that reflects traditional ecological knowledge which is called holistic thinking. According to the literature, the world was created from the air (wind). When the wind blew, it changed water in to soil; soil turned into rocks; rocks became tress and finally they became animals and human beings on earth. When there were animals; the concept of the predator was created in order to control the large amount of natural resources. Human beings had to depend and adapt themselves to nature 
appropriately. They lived their lives together with the tress and on earth (soil) which are the symbols of nature. Later on, humans tried to control nature by predating for food in order to live their lives. This reflects systematic thinking toward the ecology of Isan people from past until present.

According to the study of traditional ecological knowledge contained in the legend of Pu Sangasa-Ya Sangasi, whenever a number of anything comes together, it affects the others. For Isan people's way of life, they changed the way of searching for food in accordance with the rotation of seasons. It can be seen that Isan people have their own conception of how to live with nature. They manage natural resources systematically in order to control the number of resources. It is a management to keep balance in ecology.

Based on the traditional ecological knowledge conception, the first male and female couple on earth, $\mathrm{Pu}$ Sangasa-Ya Sangasi were created by molding clay. Then both of them had higher power over nature that brought human beings spirits. They added body and mind into the figures they moulded to make humans. This affected the thinking system and the relationship between human beings and supernatural power. At the same time, Pu Sangasa and Ya Sangasi were created by the Lord Dharma which was the symbol of wind, the representative of nature. Consequently, in Isan people's point of view, they believe that their relative spirits were also created by nature. This corresponds to Pierotti and Wildcat in that the traditional ecological knowledge is an idea focusing on the realization of relation or relationship between human and non-human. The combination of the non-human and the ethical code of human behavior expressed the relationship between humans and the supernatural, humans and human, nature to rely on nature. This concept has been inherited and transmitted through the Northeast folk literature until now.

The work "Khun Borom or Nam Tao Pung" describes why people were different in their complexions, their lifestyles as well as their group identities. The cultural meaning given by this work tends to explain social classes of people. The work states that humans were born in Nam Tao. Each of the tribes such as Tai Lem or Tai Lom and Tai Wee had the same dark complexion because they were delivered from Nam Tao through the hole drilled with heated steel. The literature also reveals the pressure existing among classes of people regarding the color of their complexion; and these people were in class of slavery. On the other hand, Tai Lerng, Tai Lor and Tai Kwang were delivered through the hole made by a chisel and, their complexions were not burned and they were white; so, they were classified as upper class with freedom. It is obvious that social class of rulers and those who were ruled are presented through the literature as well. When considering the centralization of power, in Lan Chang Empire, Tai Lor people were ruled by Khun Lor. Khun Lor was one on Khun Borom's sons. He built up the empire of Chawa or Luang Prabang to become the center of Lan Chang Empire. Representing social class so as to explain cultural meaning reveals the pressure over the other groups that forced them to admit and accept to be under those people who were created to be in the social class or 
rulers or the dominant class through the discourse "PhraYa Taen's order". In the work, Phra Ya Taen as the person ordering his men to drill the hole in Nam Tao Pung implies all groups of people were born from Nam Tao Pung. However, the use of a chisel and heated steel made these people be born with different roles. Thai Lor were classified as group of rulers; they had higher power and right over the other groups. This is called "Phra Ya Taen's Order". It is also believed that the work was aimed at transferring cultural power within the empire of the rulers.

In terms of traditional ecological knowledge, one must to pay attention to the importance of nature. The content of the legend 'Nam Tao Pung' is used for explaining the myths of human creation. Since a gourd is a type of climbing tree, its vines indicate the relative bond biding groups of human beings and shows that they are in the same vines or same type. It is in summary, to praise and to pay attention to the importance of the nature that Nam Tao is important as the type of plants that creates human beings; human beings are originally from the same nature. Acceptance of non-humans as individuals and recognition of the importance of Nam Tao means to consider the relationship between human beings and nature in terms of Isan people's traditional ecological knowledge.

This concept agrees with Siraporn $\mathrm{Na}$ Talarng's statement about the legend of 'Tai Ethnic Group' in the analytical book of Tai creation myth describing the ethnic groups of people in the North of Usakaney. The legend describes how different ethnic groups are created from generation to generation. It is popularly told by the people in this area. Consequently, the hierarchy of ethnicities is arranged differently. For example, some legends arrange the groups form Viet, Lao, Jam and Mon; in Lo Lo legend, there are Yao and Lao and in Yao legend the people poured out from the gourd and were divided into different categories. As a result, traditional ecological knowledge is not only widely expanded among the group of Isan people and the group of Tai-Lao speaking people; it includes the group of AustroAsiatic speaking people or Mon-Khmer, such as Lua, Lawa and Kha. This is dependent on the different legends of different groups of people (Siraporn $\mathrm{Na}$ Talarng, 2002:84)

\section{References}

Berkes, Friket. 1999. Sacred Ecology: Traditional Ecological Knowledge and Resource Management. Philadelphia, PA: Taylor \& Francis.

Chaiyasin, Dhanupol. 1994. Tales of Pu Sangasa and Yah Sangasi. Loei: Art and Cultural Center. Loei Teachers College. . n.d. Nitan Khun Borom

(A tale of Khun Borom): An analysis of Isan Folk Literature. Loei : Loei Rajabhat University.

Nathalang, Siraporn. 2002. Tai Peoples: Perspectives from Folklore and Folk Literature. Bangkok: Matichon.

Pierotti, Raymond and Wildcat, Daniel . 2000. Traditional ecological knowledge: The third alternative. Ecological Applications. 10: 1333-1340. 
Somdej Mahavirawong (Oun

Tissamahathera). n.d. Dictionary of

Isan - Thai Language.

Somjitsripanya, Supon. 1992. Nitan

Patomkappa. Mahasarakham: Cultural

Center, Mahasarkham Teacher Collage.

Sungkhapantanont, Thanya. 2010.

Ecocriticism : Discourse of Nature and

Environments in Thai Literature.

Doctoral dissertation, Graduate School.

Naresuan University.

2013. Ecocriticism in Thai

Literature. Pathum Thani :

Nakhon.

Yomjinca, Mataneeya. (Commentary). 1998.

Human and Nature. 3rd Edition.

Bangkok: Chulalongkorn University. 